\title{
The Role of Vocational Education in the Acceleration Preparation of Skilled Labor and Government Policy Standardizing Indonesian Labor in the Framework of ASEAN Economic Community Application
}

\author{
Wiwik Wahyuni ${ }^{1 *}$ \\ ${ }^{1}$ Lecturer-Universitas Negeri Malang. \\ *Corresponding author e-mail: wiwik.wahyuni12@gmail.com
}

\begin{abstract}
The progress of a nation and country cannot be separated from the progress of education field, because education is an integral part and cannot be separated from the process of preparing human resources quality, firm and skilled. Vocational education is an education which prepares learners to work in a particular field of expertise. The vocational education is one kind of national education and has a very important role in preparing the whole person, both as a labor and as a citizen of society and nation. It is in line with the Vision of National Education that is in 2025 Education System is a central in building character and improving the quality of human resources. The superiority of a nation is no longer dependent on natural wealth, but it depends on the superiority of human resources.This is reflected by the existence of several government policies through the development of Competence-Based Human Resources, education system competence based (UU 20/2004 on SISDIKNAS), Competence-Based Training system and Certification CompetenceBased (UU 13/2003 on Employment and PP 31 / 2006 on National Work Training System) as well as competence-based Human Resource development policy. Implementation of Indonesia National Certification has prepared several things through Labor Law No. 13/2003 and PP 23/2004 on National Board of Professional Certification that has been prepared system, structure, institution and guidance of certification of competence.
\end{abstract}

Keywords: vocational education, acceleration preparation of skilled labor, AEC

\section{INTRODUCTION}

The function of education is to continue social order and values that exist within society and as a social renewal agent so that it can anticipate the future. According to Tilaar (2006), education has prepatoris and anticipatory function that is besides preparing learners as a future generation (labor), the education also prepares the learners to anticipate the possibility of future by providing the abilities and behaviors which are needed.

The vision of national education system above is essentially devoted to prepare the Indonesian people as a whole, intact in potential and intact in insight (Sumitro, dkk.1998). The whole in potency includes the potential of body and its five senses, the potential of thinking, the potential of taste, the potential the potential of inventiveness, which includes creativity, fantasy, imagination and imagination, the potential of work, the potential of conscience which is conscience cognition, heart and feelings. Intact in insight is that value-conscious human beingswhich is insight into the hereafter, physical \& spiritual insight, individual and social insight, and insight into time which is in the past, present and future.

\begin{abstract}
Vocational education which is a kind of national education also has an important rules in preparing the whole person, as well as labor or citizen and nation. The impact of globalization which is marked by technological advances which cause vocational school assessed still not optimal in providing human resources as labor.

The vocational education has not been able to maximize the impact of technological advances in the labor market. According to Tilaar (2006), nowadays there are four main crisis in national education which are quality of education problem, relevance or external efficiency, ethylism and management. The quality of education concerns standard content, process, facilities and infrastructure, educator, and other standards. The educational relevance of skilled labor in sufficient quantities for development sector needs.

Indonesian people must be ready for $\mathrm{AEC}$, one of the important factors in AEC is that preparing skilled labors who have skill that can be equalized to other countries. One of programs that can prepare and engineer toward the development of Indonesian society in the future is education, Tilaar (1994) and PBB consider education program is one of administrators in human development. As one of national education system, Vocational
\end{abstract}


Education is education in the middle level which gives priority to the development of learners' ability to be able to work in a particular field, adaptation ability in a work environment, seeing job opportunities and selfdevelopment.

The progress of a nation and country cannot be released from the progress in education field, because education is a part of integral which cannot be apart from the process of preparing qualified human resources, firm and skilled. Vocational Education is an education which prepares the learners to work in a particular field. Vocational Education is one of National Educations and has a very important role in preparing the whole human beings, both as a labor and as a citizen of society and nation. It is in line with the Vision of National Education which is in 2025 National Education System that aspires to produce Smart and Competitive Indonesian Man.

Competitive is meant as a superior personality and always wants to be excellent, having high motivation, independent, never giving up, building and developing networks, friendly with change, innovative, and becoming agent of change, productive, quality conscious, globaloriented, and lifelong learners. To create skilled qualified and professional Human Resources, so that education must be qualified because of qualified education, it can be created Human Resources that is skilled, qualified and professional. It is as provision to face AEC (Asean Economic Community), labor competition in AEC will be very tight, however in a free market world AEC Indonesia will be flooded by labor and entrepreneur from foreign Country in ASEAN area, without Human Resources who skilled, qualified and professional that is possessed by Indonesia, almost can be confirmed Indonesia only will be good audience in their own country without taking any role.

\section{DISCUSSIONS}

As we knows that Asean Economic Community(AEC) or Masyarakat Ekonomi Asean (MEA)is a program which focuses on the economic field of ASEAN member countries. It is based on belief and also to strengthen regional competitiveness to face global and regional competition, the countries which are included into ASEAN forum has agreed to improve integration process between the countries of ASEAN Economic Community (AEC) or Masyarakat Ekonomi ASEAN (MEA).

One of the steps to reach ASEAN goals which is to strengthen the spirit of economic and social stability in South East Asia area is thatthe application ASEAN Economic Community (AEC). There are four pillars of ASEAN Economic Community, including highly competitive economic region, integration into the global economy and the last pillar is to make ASEAN a single market and a unified production base through goods and services, investment, capital and skilled labor (Bappenas 2009).

The superiority of a nation depends on nature wealthy, but it depends on human resources superiority which is educators that be able to answer the challenges which are too fast. So that graduated school students are able to adapt dynamically to the changes and challenges that exist then the government released various policies that can support and provide widespread space for schools and communities to determine programs and personal development plans which are adjusted with the needs and condition of each in facing ASEAN Economic Community.

How Indonesian society in responding to the flow of changes that occur with the enactment of the MEA. The enforcement of AEC is a challenge and also opportunity for Indonesian labor and must be responded positively, excited, passionate and working hard for mutual prosperity, especially in the face of free flow of skilled labor.

Commitment to actualize ASEAN Economic Community has to be implemented, where flow of goods and services among ASEAN countries will be free to cross the borders between the countries physically and administratively without any obstruction. The implementation of MEA will remove obstacles to the flow of investment goods and services between ASEAN countries. As the main purpose of liberalization program in the ASEAN countries is for the welfare and prosperity of ASEAN countries' people, but if the country is not ready it will have negative impact toward the country.

Education is a central in building characters and for improving Human Resources quality. Education is closely related to development and efforts to produce qualified human resources and can support the development that has been planned by the government. It is reflected by the existence of several government policies through the development of competency- based human resources, competency-based education system (UU 20/2004 about SISDIKNAS), competency-based training system and competency-based certification (UU 13/2003 about employement, and PP 31/2006 about National Training Work System)as well as competency-based human resource development policy in sector. The implementation of National Certification Indonesia has prepared several things through UU 13/2003 about employment and PP 23/2004 about National Certification Institution of Profession that has been prepared system, structure, institutional, and guidelines for competency certification. However, there are still some incomplete features in building competency-based human resources to face the implementation of the ASEAN Economic Community, the Indonesian National Competence Standards are still limited, the package and Certification Scheme of Indonesia National Qualification and the very limited National Occupational Qualification, the application of Training Competency-Based Work and Education as well as a limited Qualification Framework.

With the existence of these obstacles cause Indonesia is still very limited in producing skilled labor who is national qualified even international. By that condition, therefore Indonesia tries to be able to reach the targets.

As agreed by ASEAN countries which are joined into ASEAN is to achieve mutual prosperity, each country must prepare itself and must have provision in facing 
ASEAN Economic Community (AEC) that local labor must have the competencies that have been required and agreed by the member countries of ASEAN, it aimed to standardize qualified local labor so that it can be equal with qualified foreign labor. Vocational High School is assumed as one of places to produce expert labor later. So that, they must be completed by education and skills that have been standardized with the legality that has been recognized a certificate. Related to that matter, the Education and Culture Official (Dikbud) with National Certification Institution of Profession (BNSP) organize competency test in vocational schools that have purposes in order the knowledge and skills that students have as a prospective worker in the middle level can have legality, because beside the knowledge that is obtained from school , skill is also an important aspect that SMK students' have, they can avoid occurrence missmatch between education institution and willingness of labor market, besides it, it is also useful for the students that have competency certificate, they will get recognition, remuneration, and career level from company, because the competency certificate is as an effort to see competency that the students have, therefore there is synchronization between Human Resources and labor users.

Tourism sector becomes one of the sectors which is the most ready to face ASEAN Economic Community (AEC) which is the implementation of ASEAN MRA in "free flow of skill labor". By assigning the ASEAN MRA in 2009 which aimed to make professional mobility easy in tourism sector, to exchange information about best practices in education and training competence-based. MRA (Mutual Recognition Arrangement) is an agreement between ASEAN countries in harmonization of competent standard, harmonization of qualifications, harmonization of training and education-based systems accreditation/ licensing of educational/ training/ certification institutions which is designed to facilitate the free movement and work of qualified and certified personnel among ASEAN member countries. In order to recognize the qualifications of labor between ASEAN countries and to qualify for work in host country, it requires an equivalent and qualified competency standard, competency-based training system and certification system, as defined in CATC which is released by TPCB in ASEAN countries member. The development of KKNI certification scheme of national occupational certification scheme, implementation of KKNI and national occupation on vocational education and job training, development and application of scope of KKNI and KON certification scheme, certification according to KKNI certification scheme and national occupation, and qualification registration based on ATPRS.

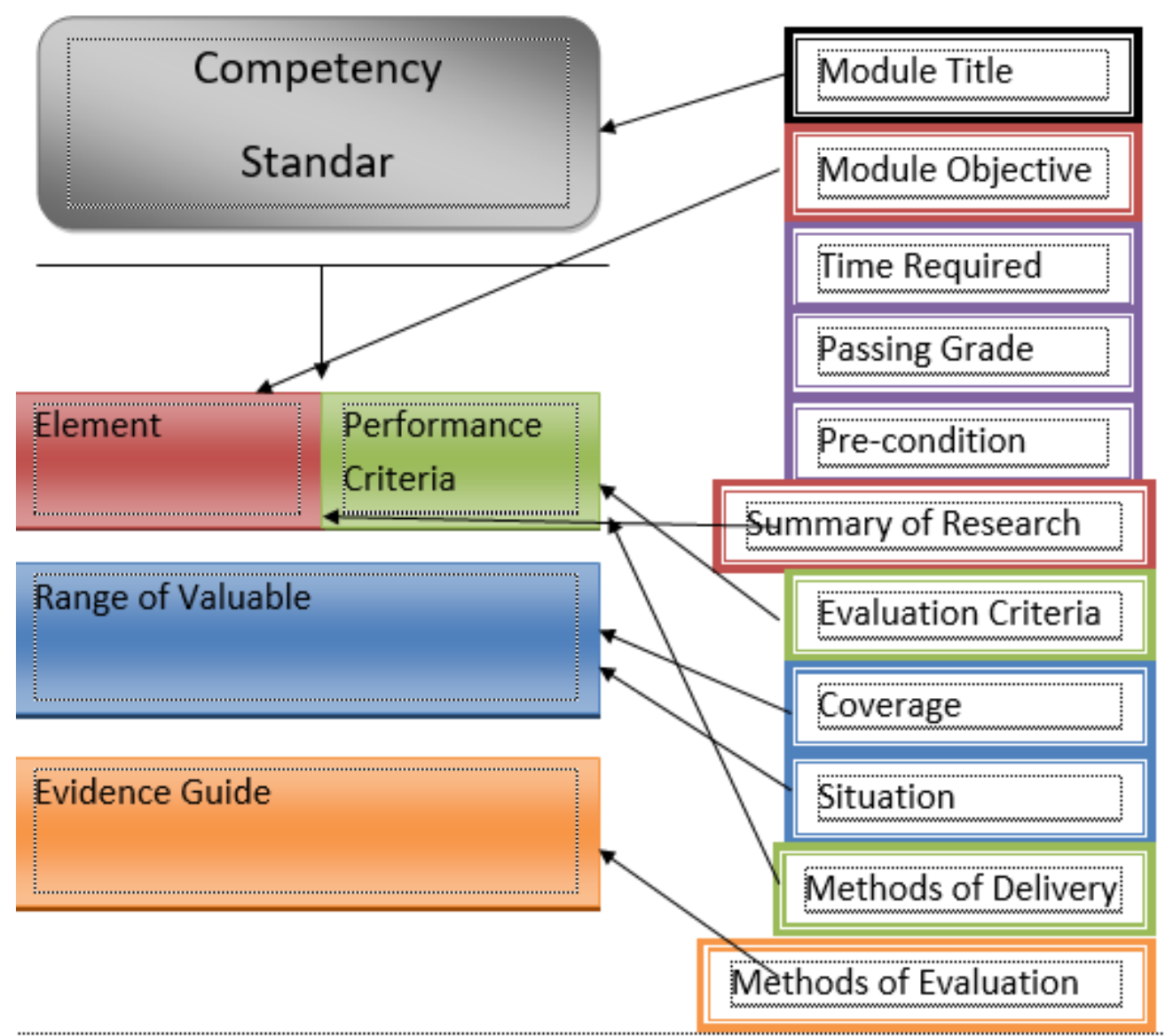

Picture Of Curriculum And Traceability To Competency Standard 
quality of qualified labor will be created if the quality of

\section{CONCLUSION}

As time goes by, Indonesian citizen must be ready to face AEC that has become agreement of ASEAN countries in a framework to increase the prosperity and also to strengthen the regional competitiveness in facing global and regional competition. Indonesia is willing or not to be involved in the process of globalization and the increasingly widespread competition in various forms such as the flow of goods and services of labor and capital flows. AEC is one of opportunities and also challenge for Indonesia in facing economic era of ASEAN.

The countries which are joined in ASEAN Economic Community will cooperate in development and improvement human resources community, recognition of professional qualifications, macroeconomic and financial policies of trade finance, improvement of infrastructure and communications connectivity, the development of electronic transactions through e-ASEAN, integrating industries throughout the region to promote their respective regional sources.

Indonesian government must be as soon as possible to do improvement starting from infrastructure improvement till the improvements in creating skilled, qualified and professional human resources. The government's task and relevant stakeholders is to prepare superior and highly competitive human resources by ensuring the development of a linear economy with the development of human. The
Indonesia human development is superior competitive and access to other public facilities will determine the quality of human and Indonesian labor.

\section{REFERENCES}

[1] Andini, 2008. pendidikan Kejuruan One 1thousand 100 education.wordpress.com/ 180k diakses tanggal 29/3/ 2009

[2] Djohar, A. 2012. Pendidikan Teknologi dan Kejuruan. (Online)

[3] Herminanto Sofyan, 2008. Optimalisasi Pembelajaran Berbasis Kompetensi pada Pendidikan Kejuruan Otomotif. Pidato Pengukuhan Guru Besar di Unuversitas Negeri Yogyakarta, tanggal 16 Februari 2008

[4] Tilaar, D.A.R. 2006. Manajemen Pendidikan Nasional. PT. Remaja Rosda Karya, Jakarta 2006

[5] Wardiman Djojonegoro. 1998. Pengembangan Sumber Daya Manusia Melalui SMK. PT. Jayakarta Agung Offset. Jakarta 